\title{
Sex hormone patterns in women with multiple sclerosis as related to disease activity - a pilot study
}

\section{Profil hormonalny u kobiet chorych na stwardnienie rozsiane w powiqzaniu z aktywnościq choroby - doniesienie wstępne}

Beata Zakrzewska-Pniewska', Marek Gołębiowski², Małgorzata Zajda', Wojciech Szeszkowski², Aleksandra Podlecka-Piętowska', Monika Nojszewska'

'Department of Neurology, The Medical University of Warsaw, Poland

${ }^{2}$ Department of Radiology, The Medical University of Warsaw, Poland

Neurologia i Neurochirurgia Polska 2011; 45, 6: 536-542

\begin{abstract}
Background and purpose: The influence of sex hormones on immune system activity in multiple sclerosis (MS) has been suggested by clinical evidence. The aim of the study was to analyse the pattern of sex hormones in MS women and to correlate the hormone pattern abnormalities to the disease course as well as to the magnetic resonance imaging (MRI) results. Material and methods: We studied the serum level of the progesterone, $\beta$-oestradiol and prolactin in 46 women with clinical definite MS aged from 19 to 65 ; mean disease duration was $11.80 \pm 9.86$ years. The evaluation of the intensity of hormonal changes was done using a scoring system (0-3). On the brain MRI, the presence of brain atrophy, of hypothalamic demyelination as well as demyelination intensity (or degree) were analysed. The evaluation of the degree of demyelination and brain atrophy was done using a scoring system (0-4).

Results: The main hormonal abnormalities consisted of decreased progesterone level, increased oestradiol level or both. The sex hormone pattern was abnormal in $56 \%$ of patients. Hypotha lamic lesions were found on MRI in 53\% of cases. The abnormal hormonal pattern correlated with intensity of MR changes ( $p<0.05$, Fisher's exact test), but neither with presence of hypothalamic changes nor with disease parameters (Expanded Disability Status Scale, relapse rate, disease duration).
\end{abstract}

\section{Streszczenie}

Wstęp i cel pracy: Dane z piśmiennictwa sugerują częste występowanie zaburzeń hormonalnych u kobiet chorych na stwardnienie rozsiane (SR). Celem pracy była analiza profilu hormonalnego w zakresie hormonów płciowych u kobiet z SR w powiązaniu z przebiegiem klinicznym i obrazem rezonansu magnetycznego (RM) mózgowia.

Materiał i metody: Badano stężenie progesteronu, $\beta$-estradiolu i prolaktyny w surowicy u 46 pacjentek $\mathrm{z}$ klinicznie pewnym SR, w wieku od 19 lat do 65 lat, o średnim czasie trwania choroby $11,80 \pm 9,86$ roku, niestosujących żadnej terapii hormonalnej. Stopień zmian w profilu hormonalnym oceniano półilościowo wg przyjętego arbitralnie przez autorów systemu punktacji (0-3).W analizie RM brano pod uwagę obecność ognisk demielinizacji w obrębie struktur podwzgórza, nasilenie demielinizacji w obrębie mózgowia oraz współistnienie zaniku mózgu. Stopień zmian w RM oceniano także półilościowo wg przyjętego arbitralnie przez autorów systemu punktacji (0-4).

Wyniki: Nieprawidłowe stężenia hormonów stwierdzono u 26 pacjentek (56\%). Nieprawidłowości polegały na zmniejszonym stężeniu progesteronu, zwiększonym stężeniu $17-\beta$-estradiolu bądź na łącznym występowaniu obu tych zaburzeń. W badaniu RM w 53\% przypadków stwierdzono

Correspondence address: Beata Zakrzewska-Pniewska, MD, PhD, Ass. Prof., MS Unit, Department of Neurology, The Medical University of Warsaw, la Banacha St., 02-097 Warsaw, Poland, phone +48 22599 28 90, fax +48 22599 12 57, e-mail: beata.zakrzewska-pniewska@wum.edu.pl Received: 13.08.2010; accepted: 7.07.2011 
Conclusions: It is important to check the hormonal pattern in MS women because according to our results it may be related to the disease activity and probably affects the type of therapeutic intervention. This pilot study will be extended in a larger population.

Key words: sex hormones, MRI, multiple sclerosis.

\section{Introduction}

Multiple sclerosis (MS) is an autoimmune disease, characterized by a chronic inflammatory demyelinating process in the central nervous system (CNS). Females have an increased risk of developing autoimmune diseases such as rheumatoid arthritis (RA) and MS compared to males. Relapsing-remitting MS (RRMS) affects females two to three times more often than males [1-3]. Although the mechanism for gender disproportion related to susceptibility and disease progression in MS is unclear, increasing evidence suggests that sex hormones play an important role [4-8]. For example, the clinical signs of MS usually appear in young adults, after sexual maturity. Other periods of change in serum sex hormone concentrations, such as during menstruation and the menopause, may also negatively affect the course of MS [9-11]. Little is known about the influence of oral contraceptives on the modulation of the disease activity in MS [12]. More evidence for a role of sex hormones in MS is observed during pregnancy [13-15]. Indeed, increased level of sex hormones produced during pregnancy have been reported to reduce the severity of MS, whereas in a period of time marked by reduced sex hormones, such as the postpartum period, clinical symptoms of MS often increase. Pregnancy is associated with enhanced humoral and decreased cellular immune activity $[16,17]$.

The goal of this article is to analyse the pattern of sex hormones in MS women and to correlate the hormonal pattern abnormalities with the clinical course of the disease and to the magnetic resonance imaging (MRI) results. obecność zmian demielinizacyjno-zapalnych w obrębie podwzgórza. Stopień zaburzeń hormonalnych oceniany pótilościowo korelował ze stopniem zmian w RM mózgowia ( $p<0,05$; test dokładny Fishera), nie był natomiast związany z obecnością zmian w obrębie podwzgórza czy parametrami klinicznymi (punktacja w Expanded Disability Status Scale, częstość rzutów, czas trwania choroby).

Wnioski: Stan hormonalny kobiet chorych na SR powinien być brany pod uwagę $\mathrm{w}$ analizie klinicznej choroby i przy decyzjach terapeutycznych, gdyż wydaje się mieć związek z aktywnością SR. Badania te, w celu potwierdzenia uzyskanych wyników, należy kontynuować na szerszym materiale.

Słowa kluczowe: hormony płciowe, rezonans magnetyczny, stwardnienie rozsiane.

\section{Material and methods}

\section{Subjects}

The study group included 46 women with clinically definite MS diagnosed according to the criteria proposed by McDonald et al. [18]. The control group for hormonal study consisted of 50 healthy women matched for age and hormonal status (premenopausal and postmenopausal).

Sex hormone levels obtained in the control group of healthy women were usually accepted as normal; if in a given case results markedly exceeded the limits obtained in the control group ("outsiders") that person was not included in the control group. The hormone mean values and ranges found in controls are presented in Table 1.

The patients were recruited from MS Outpatient Clinic and MS Unit, Department of Neurology, The Medical University of Warsaw. Their characteristics are provided in Table 2. There were 27 patients with RRMS, 12 with secondary progressive course (SPMS) and 7 with

Table 1. Hormone value ranges in controls

\begin{tabular}{|c|c|c|}
\hline \multirow{2}{*}{$\begin{array}{l}\text { Menstrual cycle } \\
\text { phases }\end{array}$} & \multirow{2}{*}{$\begin{array}{c}\text { 17- } \beta \text {-oestradiol } \\
\text { Mean and range } \\
(\mathrm{pg} / \mathrm{mL})\end{array}$} & \multirow{2}{*}{$\begin{array}{c}\text { Progesterone } \\
\begin{array}{c}\text { Mean and range } \\
\text { (nmol/L) }\end{array}\end{array}$} \\
\hline & & \\
\hline Follicular phase & $\begin{array}{c}102.0 \\
(35.0-169.0)\end{array}$ & $\begin{array}{c}2.10 \\
(1.21-2.99)\end{array}$ \\
\hline Ovulation & $\begin{array}{c}238.0 \\
(49.0-427.0)\end{array}$ & $\begin{array}{c}\text { Not } \\
\text { detectable }\end{array}$ \\
\hline Luteal phase & $\begin{array}{c}122.0 \\
(53.0-191.0)\end{array}$ & $\begin{array}{c}55.31 \\
(24.71-85.90)\end{array}$ \\
\hline $\begin{array}{l}\text { Postmenopausal } \\
\text { period }\end{array}$ & $\begin{array}{c}64.0 \\
(18.0-110.0)\end{array}$ & $\begin{array}{c}1.08 \\
(0.60-1.56)\end{array}$ \\
\hline
\end{tabular}


Table 2. Demographic characteristics of multiple sclerosis patients

\begin{tabular}{|lc|}
\hline Characteristics & Multiple sclerosis patients \\
\hline Number of patients & 46 \\
\hline $\begin{array}{l}\text { Age [years]; } \\
\text { mean } \pm \mathrm{SD} \text { (range) }\end{array}$ & $39.28 \pm 11.67$ (19-65) \\
\hline $\begin{array}{l}\text { Multiple sclerosis duration } \\
\text { [years]; mean } \pm \mathrm{SD} \text { (range) }\end{array}$ & $11.80 \pm 9.86(0.5-39.0)$ \\
\hline $\begin{array}{l}\text { Relapse Index; } \\
\text { mean } \pm \mathrm{SD} \text { (range) }\end{array}$ & $2.24 \pm 2.60(1-12)$ \\
\hline EDSS; mean $\pm \mathrm{SD}$ (range) & $3.51 \pm 1.71$ (1-7) \\
\hline
\end{tabular}

Table 3. Magnetic resonance imaging (MRI) analysis: scoring system

\begin{tabular}{|ll|}
\hline $\begin{array}{l}\text { MRI abnormalities } \\
\text { (scores) }\end{array}$ \\
\hline 0 & Normal brain MRI \\
\hline 1 & Moderate multifocal demyelination \\
\hline 2 & Marked multifocal demyelination \\
\hline 3 & Marked diffuse demyelination \\
\hline 4 & $\begin{array}{l}\text { Marked diffuse and multifocal } \\
\text { demyelination and brain atrophy }\end{array}$ \\
\hline
\end{tabular}

Table 4. Hormone pattern analysis: scoring system

\begin{tabular}{|lll|}
\hline $\begin{array}{l}\text { Hormone } \\
\text { abnormalities } \\
\text { (scores) }\end{array}$ & $\begin{array}{l}\text { Progesterone } \\
\text { serum level }\end{array}$ & $\begin{array}{l}\text { 7- } \beta \text {-oestradiol } \\
\text { serum level }\end{array}$ \\
\hline 0 & Normal & Normal \\
\hline 1 & Decreased & Normal \\
\hline 2 & Normal & Increased \\
\hline 3 & Decreased & Increased \\
\hline
\end{tabular}

relapsing-progressing MS (RPMS). Hormonal and MRI studies were performed during thet follicular phase in 14 patients, during the luteal phase in 12 patients, during ovulation in 1 woman. In 19 women hormonal evaluation has confirmed postmenopausal state. Neither patients nor controls have received any hormonal therapy, including hormonal contraception. There was no relevant gynaecological history in the control group. The patients' gynaecological symptoms and signs were also insignificant except for mild menstrual disturbances occurring in $50 \%$ of patients, consisting of irregular menstruation. All subjects gave their informed consent prior to their inclusion in the study. Brain MR as well as hormonal panel are a part of the standard procedures performed in the MS Unit.

\section{Magnetic resonance imaging}

On MRI examination, conventional spin echo sequen ces were used to obtain proton density and $\mathrm{T} 2$-weighted images of the brain. The Tl-weighted images were also analysed. The MR images were evaluated according to an arbitrarily proposed semi-qualitative scoring system used in our MS Unit. Such evaluation was performed by an experienced neuroradiologist. It was impossible to perform qualitative MRI analysis for technical reasons. The evaluation of the degree of demyelination and brain atrophy was done using a scoring system (Table 3 ). In addition, on 36 scans it was possible to analyse the presence and then to assess the number of $\mathrm{T} 2$-weighted hypothalamic lesions.

\section{Hormonal studies}

At the day of MR study ( \pm 7 days), serum levels of $17-\beta$-oestradiol $(\mathrm{pg} / \mathrm{mL})$, progesterone $(\mathrm{ng} / \mathrm{L})$ and prolactin $(\mathrm{ng} / \mathrm{mL})$ were determined. Blood samples were stored at $-20^{\circ} \mathrm{C}$ until analysis. Single measurement of the level of sex hormones is insufficient from an endocrine and gynaecological point of view to make a precise dia gnosis of possible disturbances and in this study it serves only as a basis for preliminary conclusions and for comparison with the control group. Hormonal evaluations were blinded and performed in a single radioimmunoassay for each hormone. The evaluation of the intensity of hormonal changes was done using a scoring system (Table 4). The hormone levels were analysed separately for each hormone and for each hormonal phase. For example, the progesterone level was considered abnormal in the follicular phase if it was $<1.21 \mathrm{nmol} / \mathrm{L}$ or $>2.99 \mathrm{nmol} / \mathrm{L}$.

\section{Statistical analysis}

Values are presented as mean $\pm \mathrm{SD}$ as well as means and ranges. The Spearman correlation coefficients test was used to study the correlations between the following variables: Expanded Disability Status Scale (EDSS), age, disease duration, relapse index and MRI as well as hormonal scores. Wilcoxon rank-sum test was used to analyse the differences between patients and controls. Fisher exact test was used to study the associations between different parameters, i.e. hormonal and MR scores in different subgroups. Statistical significance was defined as $p<0.05$. 


\section{Results}

\section{Hormonal changes}

The mean hormone levels in the MS patient group were as follows: $137.7 \pm 144.26 \mathrm{pg} / \mathrm{mL}$ for oestradiol, $6.41 \pm 11.59 \mathrm{nmol} / \mathrm{L}$ for progesterone and $93.29 \pm$ $344.21 \mathrm{ng} / \mathrm{mL}$ for prolactin (prolactin level ranges in controls were from 1.2 to $29.93 \mathrm{ng} / \mathrm{ml}$ ). These results in different cycle phases (hormones' mean values and ranges) compared with the control group are presented in Fig. 1. The oestradiol level was abnormal in 12 patients (26.1\%), the progesterone level in $21(45.6 \%)$ and the prolactin in 5 cases (10.9\%). Because of the small number of patients in each subgroup, statistical comparison of the sex hormone level differences between MS patients and the control groups in particular phases of the menstrual cycle was not possible. The distribution of the degree of hormonal changes (in scores) is presented in Fig. 2. In general, hormonal abnormalities were found in $26 \mathrm{MS}$ women $(56.5 \%)$ and were usually of mild intensity (score 1).

\section{Magnetic resonance imaging changes}

Hypothalamic lesions were found on MRI in 17 of 36 analysed cases (53\%). The distribution of the degree of MR changes (in scores) is presented in Fig. 3. This distribution was almost equal for scores 1,2 and 4 .
A

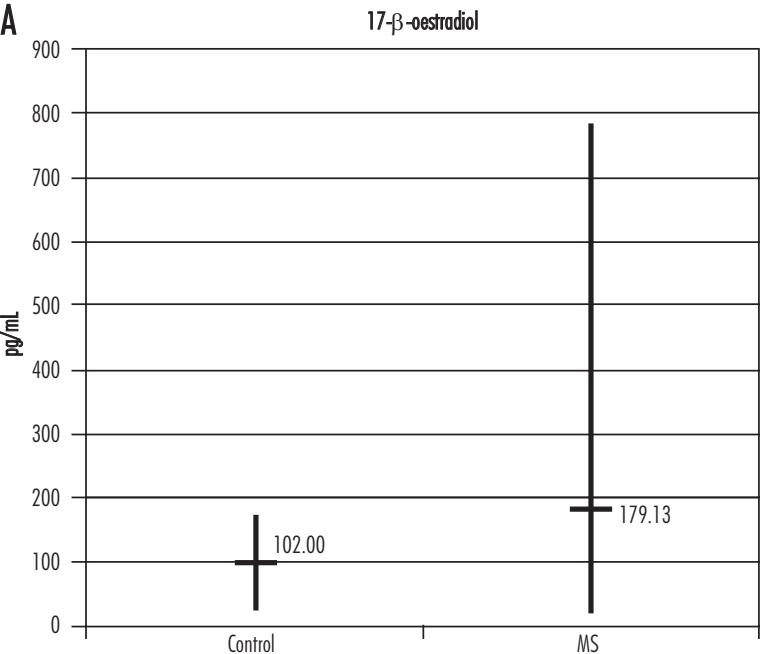

B

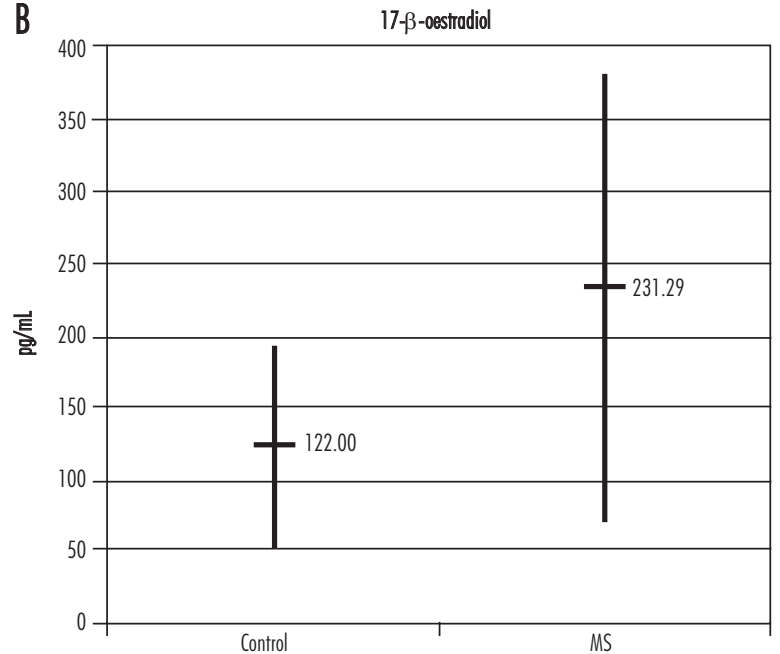

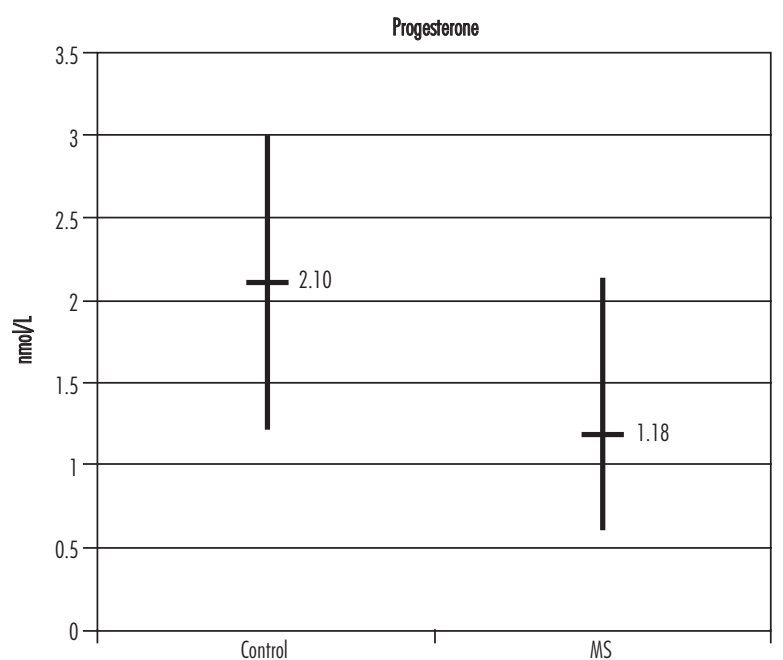

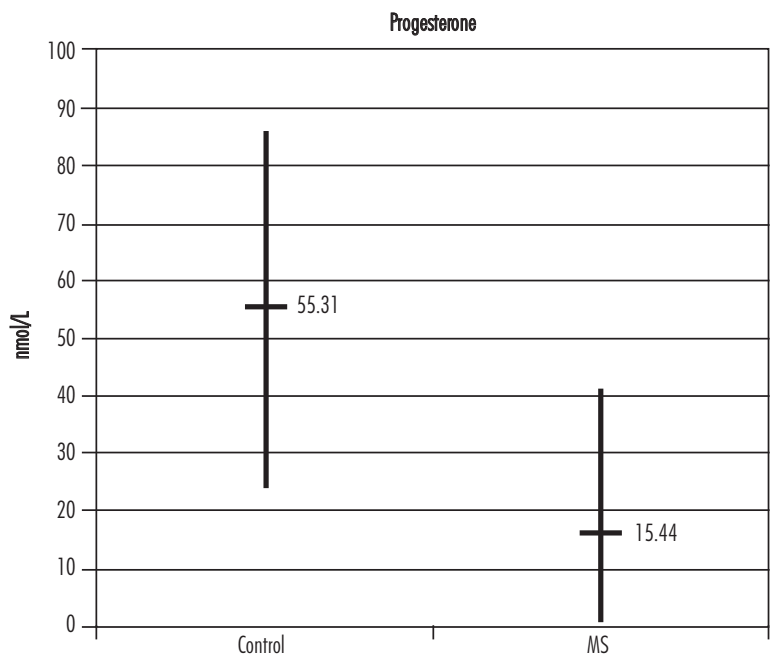

Fig. 1. Hormone levels in multiple sclerosis (MS) patients and controls (means and ranges): A) follicular phase and B) luteal phase 


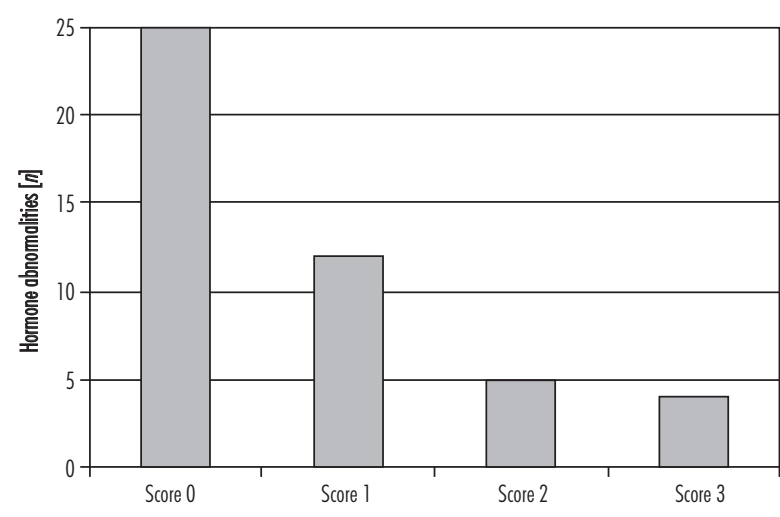

Fig. 2. Hormonal abnormalities distribution (in scores) in multiple sclerosis patients

\section{Hormonal versus MR changes}

The significant associations were found between hormonal and MR score distribution if studied by Fisher's exact test $(p<0.05)$.

Neither the hormonal nor MR scores were related to the clinical parameters (i.e. the age of the patients, the MS duration, the EDDS value as well as the relapse index).

There was no correlation between the presence and the number of hypothalamic lesions on MR and the hormonal change scores. Especially the presence and the number of hypothalamic lesions were not closely related to the prolactin level if studied by Wilcoxon two samples and by Kruskal-Wallis test.

\section{Discussion}

It seems that sex hormones play an important role in susceptibility to MS and in disease progression. In our material the oestradiol level was abnormal (increased) in about one-fourth of patients, whereas both oestrogen (high) and progesterone (low) levels were abnormal in about half of patients.

Oestrogen has a dichotomous effect on the immune system [19]. For example, T cell development in the thymus is suppressed, whereas antibody production is stimulated by oestrogen $[20,21]$. Furthermore, oestrogen decreases T-cell mediated delayed-type hypersensitivity $[21,22]$, granulocyte-mediated cytotoxicity and natural killer-mediated cytotoxicity [22,23]. Oestrogens are considered to differentially affect immune responses during pregnancy, during the menstrual cycle, and in postmenopausal women $[6,19]$. During pregnancy, oestrogens play an important role in regulating physiological events essential to the maintenance of the fetus and the

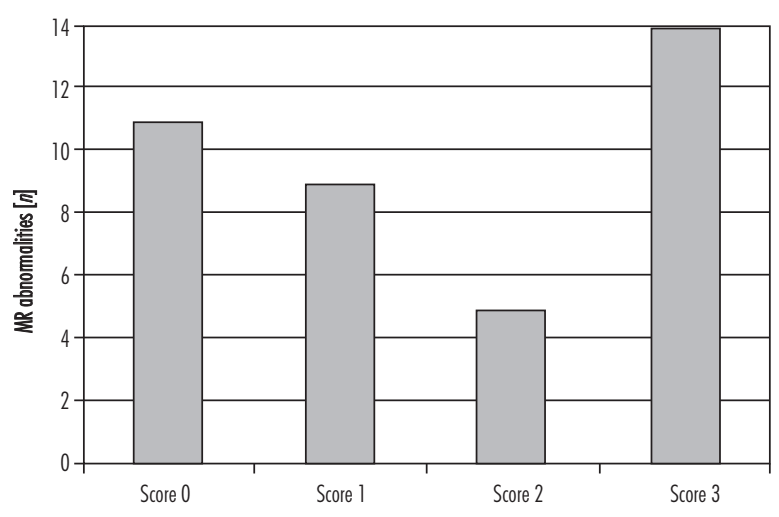

Fig. 3. MRI abnormalities distribution (in scores) in multiple sclerosis patients

protection of the mother, but may also influence the clinical course of MS [24-26]. Indeed, in MS it is well known that late pregnancy affords temporal remission of MS attacks [27]. The clinical remission is also associated with a decrease of the disease activity on the MRI [28-30]. Women who first developed symptoms of MS during pregnancy experience less subsequent disability than women who developed the disease at any other time [31]. Besides the possible immune modulation by oestrogen during pregnancy, it can be anticipated that oral contraception similarly affects the immune system. Although no data in MS have been reported about the long-term effects of oral contraception, the effects of oral contraception in rheumatoid arthritis (RA) have been debated. No definite conclusion could be drawn, since a beneficial effect has been documented in some earlier studies, while in others oral contraception has no effect [32-35]. This may reflect the reduced amount of oestrogen in more recent oral contraceptives and the use of synthetically modified oestrogen [36].

The exact role of progesterone in MS remains unclear $[37,38]$. It might modify the cytokine production in MS [39]. Pozzilli et al. [40] found that increased ratio of progesterone $/ 17-\beta$-oestradiol during the luteal phase was associated with both a high number and volume of enhancing lesions on MRI. In our study we have confirmed the relationship between this ratio and the degree of MR changes. During pregnancy, the placenta produces a high level of progesterone responsible for the immunosuppressive effect. Contrarily, Correale et al. [14] found in MS that progestrone, in concentrations similar to that found in the peripheral circulation during the normal menstruation, during pregnancy, as well as in pharmacological doses, enhanced secretion of IL-4 by peripheral CD4+ T cells. Since IL-4 plays an important role in 
the development of Th2 cells, progesterone seems to be a good candidate for their promotion.

In our study we analysed the MR abnormalities in relation to hormonal changes. The clinical remission in MS is usually associated with a decrease of the disease activity on the MRI [28]. Some studies revealed gender-associated differences in clinical evolution of MS as well as in the evolution of MRI findings. Female patients are more likely to develop more inflammatory but less destructive lesion pathology. There was a trend toward higher lesion volume in T1-weighted images and higher ratio T1/T2-weighted lesions when comparing male to female with RRMS. Women showed a smaller number of Gd-enhancing lesions [41]. These results indicated a gender effect on MRI findings in MS using conventional MRI techniques [42].

We tried to correlate the MRI findings and clinical MS parameters. Our results were unrelevant. Particularly there was no relationship between hormonal abnormalities and presence and/or number of hypothalamic lesions.

\section{Conclusions}

The molecular basis for explaining the hormonal pattern related differences in MRI findings in women with MS and the underlying pathological process translating the disease activity in general, as well as in our study, in MRI-related measures remains unclear, although a divergent imbalance between demyelination, inflammation and neurodegeneration related to hormonal patterns is proposed. To confirm the obtained results our pilot study should be extended to a larger patient population.

\section{Disclosure}

Authors report no conflict of interest.

\section{References}

1. Bashir K., Whitaker J.N. Clinical and laboratory features of primary progressive and secondary progressive MS. Neurology 1999; 53: 765-771.

2. Duquette P., Pleines J., Girard M., et al. The increased susceptibility of women to multiple sclerosis. Can J Neurol Sci 1992; 19: 466-471.

3. Whitacre C.C., Reingold S.C., O'Looney P.A. A gender gap in autoimmunity. Science 1999; 283: 1277-1278.

4. van den Broek H.H., Damoiseaux J.G., de Baets M.H., et al. The influence of sex hormones on cytokines in multiple sclero- sis and experimental autoimmune encepha-lomyelitis; a revue. Mult Scler 2005; 11: 349-359.

5. Peltrey C.M., Moldovan I.R., Cotleur A.C., et al. Effects of sex hormones on costimulatory molecule expression in multiple sclerosis. J Neuroimmunol 2005; 167: 190-203.

6. El-Etr M., Vukusic S., Gignoux L., et al. Steroid hormones in multiple sclerosis. J Neurol Sci 2005; 233: 49-54.

7. Kim S., Liva S.M., Dalal M.A., et al. Estriol ameliorates autoimmune demyelinating disease. Implications for multiple sclerosis. Neurology 1999; 52: 1230-1238.

8. Shuster E.A. Hormonal influences in multiple sclerosis. Curr Top Microbiol Immunol 2008; 318: 267-311.

9. Smith R., Studd J.W. The pilot study of the effect upon multiple sclerosis of the menopause, hormone replacement therapy and menstrual cycle. J R Soc Med 1992; 85: 612-613.

10. Zorgdrager A., de Keyser J. Premenstrual exacerbations of multiple sclerosis. J Neurol Neurosurg Psychiatry 1998; 65: 279-280.

11. Zorgdrager A., de Keyser J. Menstrually related worsening of symptoms in multiple sclerosis. J Neurol Sci 1997; 149: 95-97.

12. Hernan M.A., Hohol M.J., Olek M.J., et al. Oral contraceptives and incidence of multiple sclerosis. Neurology 2000; 55 : 848-853.

13. Voskuhl R.R., Palaszynski K. Sex hormones in experimental autoimmune encephalomyelitis: implications for multiple sclerosis. Neuroscientist 2001; 7: 258-270.

14. Correale J., Arias M., Gilmore W. Steroid hormone regulation of cytokine secretion by proteolipid-specific $\mathrm{CD} 4+\mathrm{T}$ cell clones isolated from multiple sclerosis patients and normal control subjects. J Immunol 1998; 161: 3365-3374.

15. Elenkov I.J., Wilder R.L., Bakalov V.K., et al. IL-12, TNF-alpha, and hormonal changes during late pregnancy and early postpartum: implications for autoimmune disease activity during these times. J Clin Endocrinol Metab 2001; 86: 4933-4938.

16. Dudley D.J., Chen C.L., Mitchell M.D., et al. Adaptative immune responses during murine pregnancy: pregnancy-induced regulation of lymphokines production by activated T lymphocytes. Am J Obstet Gynecol 1993; 168: 1155-1163.

17. Wegmann T.G., Lin H., Guilbert L., et al. Bidirectional cytokine interactions in the maternal-fetal relationship: is successful pregnancy a Th2 phenomenon? Immunol Today 1993; 14: 353-356.

18. McDonald I., Compston A., Edan G., et al. Recommended diagnostic criteria for multiple sclerosis: guidelines from the international panel on the diagnosis of multiple sclerosis. Ann Neurol 2001; 50: 121-127.

19. Palaszynski K.M., Liu H., Loo K.K., et al. Estriol treatment ameliorates disease in males with experimental autoimmune encephalomyelitis: implications for multiple sclerosis. J Neuroimmunol 2004; 149: 84-89.

20. Rijhsinghani A.G., Thompson K., Bhatia S.K., et al. Estrogen blocks early $\mathrm{T}$ cell development in the thymus. Am J Reprod Immunol 1996; 36: 269-277.

21. Carlsten H., Holmdahl R., Tarkowski R., et al. Oestradiol- and testosterone-mediated effects on the immune system in normal and autoimmune mice are genetically linked and inherited as dominant traits. Immunology 1989; 68: 209-214. 
22. Nilsson N., Carlsten H. Estrogen induces suppression of natural killer cell cytotoxicity and augmentation of polyclonal B cell activation. Cell Immunol 1994; 158: 131-139.

23. Josefsson E., Tarkowski A., Carlsten H. Anti-inflammatory properties of estrogen. In vivo suppression of leukocyte production in bone marrow and redistribution of peripheral blood neutrophiles. Cell Immunol 1992; 142: 67-78.

24. Vukusic S., Confavreux C. Pregnancy and multiple sclerosis: The children of PRIMS. Clin Neurol Neurosurg 2006; 108: 266-270.

25. Derw P.D., Chavis J.A. Female sex steroids: effects upon microglial cell activation. J Neuroimmunol 2000; 111: 77-85.

26. Hellwig K., Beste C., Brune N., et al. Increased MS relapse rate during assisted reproduction technique. J Neurol 2008; 255: 592-593.

27. Confavreux C., Hutchinson M., Hours M.M. Rate of pregnancy-related relapse in multiple sclerosis. Pregnancy in Multiple Sclerosis Group. N Engl J Med 1998; 339: 285-291.

28. van Walderveen M.A., Tas M.W., Barkhof F., et al. Magnetic resonance evaluation of disease activity during pregnancy in multiple sclerosis. Neurology 1994; 44: 327-329.

29. Antulov R., Weinstock-Guttman B., Cox L.J., et al. Genderrelated differences in MS: a study of conventional and nonconventional MRI measures. Mult Scler 2009; 15: 345-354.

30. Bansil S., Lee H.J., Jindal S., et al. Correlation between sex hormones and magnetic resonance imaging lesions in multiple sclerosis. Acta Neurol Scand 1999; 99: 91-94.

31. Thomson D.S., Nelson L.M., Burns A., et al. The effects of pregnancy in multiple sclerosis: a retrospective study. Neurology 1986; 36: 1097-1099.

32. van Zeben D., Hazes J.M., Vandenbroucke J.P., et al. Diminished incidence of severe rheumatoid arthritis associated with oral contraceptives use. Arthritis Rheum 1990; 33: 1462-1465.

33. Vandenbroucke J.P., Witteman J.C., Valkenburg H.A., et al. Noncontraceptive hormones and rheumatoid arthritis in perimenopausal and postmenopausal women. JAMA 1986; 255: 1299-1303.

34. Hazes J.M., Dijkmans B.A., Vandenbroucke J.P., et al. Oral contraceptive treatment for rheumatoid arthritis: an open study in 10 female patients. Br J Rheumatol 1989; 28 (Suppl 1): 28-30.

35. Hernandez-Avila M., Liang M.H., Willet W.C., et al. Exogenous sex hormones and the risk of rheumatoid arthritis. Arthitis Rheum 1990; 33: 947-953.

36. Hernan M.A., Hohol M.J., Olek M.J., et al. Oral contraceptives and the incidence of multiple sclerosis. Neurology 2000; 55 : 848-854.

37. Ehrlich S., Haas J., Zipp F., et al. Serum levels of soluble CD95 are not associated with amelioration of multiple sclerosis during pregnancy. J Neurol Sci 2007; 252: 83-87.

38. Acs P., Kipp M., Norkute A., et al. 17beta-estradiol and progesterone prevent cuprizone provoked demyelination of corpus callosum in male mice. Glia 2009; 57: 807-814.

39. Garay L., Gonzalez- Deniselle M.C., Gierman L., et al. Steroid protection in the experimental autoimmune encephalomyelitis model of multiple sclerosis. Neuroimmunomodulation 2008; 15 : 76-83.
40. Pozzilli C., Falaschi P., Mainero C., et al. MRI in multiple sclerosis during the menstrual cycle: relationship with sex hormones patterns. Neurology 1999; 53: 622-624.

41. Weatherby S.J., Mann C.L., Davies M.B. A pilot study of the relationship between gadolinium-enhancing lesions, gender effect and polymorphisms of antioxidant enzymes in multiple sclerosis. J Neurol 2000; 247: 467-470.

42. Horsfield M.A. Magnetization transfer imaging in multiple sclerosis. J Neuroimaging 2005; 15: 58S-67S. 